\title{
BERZAKAT MELALUI AMIL DALAM PERSPEKTIF AL-QUR'AN DAN SUNNAH
}

\author{
Arif Zunzul Maizal \\ Dosen IAIN Batusangkar \\ Jln. Sudirman No. 137 Kubu Rajo, Lima Kaum Batusangkar
}

\begin{abstract}
Zakat, beside to the pillars of Islam and ritual-vertical worship, is a socialhorizontal worship. Because basically zakat is allowed to the ummah of Islam in order to strengthen the economics of Muslims. This matter can be seen from the cues of the meaning of zakat in the language of al-numuw (growing and developing). To relize it, zakat must be paid by muzakki in accordance to the system that has been established shari'a. Among the systems that have been neglected are the payer of zakat which is done through amil formed by the government. Because the zakat workers who are collected through amil then managed professionally will be able to make zakat as a power of potential economic for ummat economic empowerment. Based on the Law No. 38 of 1999 and revised into Law No. 23 of 2011, the Indonesian government has adopted a part of Islamic Shari'a about zakat. In the Law, it is stated that the institution which have authority to carry out the duty of the Country in the zakat management in Indonesia are the National Amil Zakat Agency (BAZNAS) with each level and the National Amil Zakat Institute (LAZNAS).
\end{abstract}

Kata Kunci : Zakat; Amil; Al-quran ; Sunnah

PENDAHULUAN

$\mathrm{Z}$ akat merupakan salah satu sendi rukun Islam yang diwajibkan kepada setiap muslim yang kekayaannya mencapai se-nishab. Di samping sebagai rukun islam zakat dan ibadah yang ritual. Zakat juga memiliki nilai social horizontal, khususnya dalam hal permberdayaan ekonomi ummat. Jika dilihat dari segi makna etimologisnya, zakat di antaranya bermakna al-numuw (tumbuh atau berkembang). Relevansinya dengan prakteknya adalah bahwa zakat diharapkan mampu menumbuhkan dan mengembangkan kehidupan umat Islam.
Zakat dapat menumbuhkembangkan rezki yang diperoleh oleh para muzakki, karena meskipun secara lahiriah hartanya berkurang tetapi pada hakikatnya dengan membayarkan zakat harta mereka tidaklah berkurang, sebgaimana jaminan Rasulullah Saw bahwa shadaqah/zakat tidaklah akan mengurangi harta. Tetapi justru dengan zakat harta atau rezki mereka semakin berkembnag baik secara kualitas maupun kuantiyasnya. sebagaimana jaminan Allah Swt dalam surat al-Baqarah ayat 261 : 


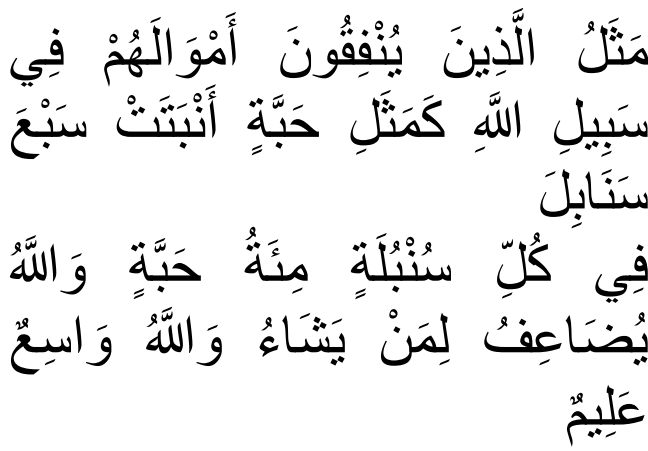

Artinya : Perumpamaan (nafkah yang dikeluarkan oleh) orang-orang yang menafkahkan hartanya di jalan Allah adalah serupa dengan sebutir benih yang menumbuhkan tujuh bulir, pada tiaptiap bulir seratus biji. Allah melipat gandakan (ganjaran) bagi siapa yang Dia kehendaki. dan Allah Maha Luas (karunia-Nya) lagi Maha mengetahui.

Di samping itu, zakat sebenarnya juga diharapkan dapat menumbuhkembangkan kehidupan orang-orang miskin, artinya zakat mampu menjadi kekuatan ekonomi umat Islam untuk mengurangi dan meminimalisir tingkat kemiskinan. Zakat dapat dijadikan sebagai modal ekonomi untuk mengangkat dan memberdayakan kehidupan orangorang miskin, sehingga dari mustahiq mereka dapat berkembang menjadi muzakki.

Untuk itu mencapai tujuan mulia tersebut sangat diperlukan pengamalan zakat secara berjamaa'ah dan pengelolaan secara professional. Untuk mengimplemenatsikan hal tersebut juga sangat diperlukan landasan syar'i tentang pengelolaan zakat . Maka melalui makalah singkat ini penulis akan mendeskripsikan tentang "BERZAKAT MELALUI

AMIL DALAM PERSPEKTIF QURAN DAN SUNNAH”

\section{BERZAKAT MELALUI AMIL}

Secara bahasa kata Amil merupakan isim fa'li dari 'amilya'malu yang berarti orang yang bekerja. Secara istilah ulama Hanafiyah berpendapat bahwa Amil adalah orang yang diangkat oleh imam (pemerintah) untuk melakukan pengelolaan zakat. Ulama Syafi'iyyah menjelaskan bahwa amil adalah setiap orang yang terlibat dalam pengelolaan zakat, baik orang yang memungut, mendistribusikan menyimpan, dan mencatat. Dari defenisi di atas dapat disaimpulkan bahwa ada dua kata kunci tentang amil zakat, pertama bekerja sebagai pengelola zakat, baik mengumpulkan, menyimpan, mencatat dan mendistribusikan, dan kedua, diangkat atau mendapatkan legalitas dari ulil amr (pemerintah).

\section{Perintah Kepada Ulil Amri (pemimpin) untuk \\ Mengumpulkan Zakat}

Di antara dalil yang memerintahkan pembayaran zakat melalui amil adalah adanya perintah kepada kepada ulil amri (pemimimpin umat Islam untuk melakukan pengumpulan dan pendistribusian zakat).

Perintah tersebut disampaikan Allah Swt kepada para pemimpin umat Islam melalui firman-Nya surat al-Taubah ayat 103: 


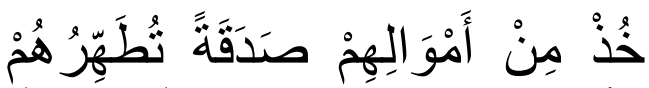

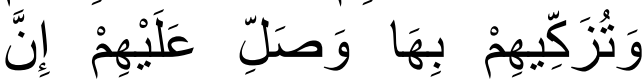

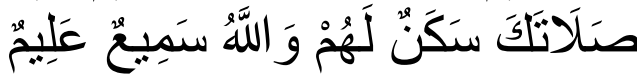
Artinya: Ambillah zakat dari sebagian harta mereka, dengan zakat itu kamu membersihkan dan mensucikan mereka dan mendoalah untuk mereka. Sesungguhnya doa kamu itu (menjadi) ketenteraman jiwa bagi mereka. dan Allah Maha mendengar lagi Maha mengetahui.(QS al-Taubah : 103)

Diriwayatkan dari Ibnu Jarir bahwa Abu Lubabah dan sahabatnya datang kepada Rasulullah, dan mengatakan, "Ini harta kami dan kami akan "mensedekahkannya", dan doakan kami supaya diampuni oleh Allah, kemudian Rasulullah menjawab, saya tidak diperintahkan untuk mengambil sesuatu pun dari hartamu, maka turunlah ayat ini(Abu Ja'far al-Thabari, Jami'ul Bayan fi Ta'wil al-Quran, h. 203)

Menurut Imam Ahmad Musthafa al-Maraghi meskipun ayat ini memiliki sebab yang khusus, namun maknanya berlaku umum, artinya perintah ini tidak hanya kepada Nabi Muhammad Saw tetapi juga untuk para penganti-penganti Rasulullah seperti Khulafaurrasysdidin dan Ulil Amri atau pemimpin-pemimpin umat Islam sesudahnya. (Ahmad Musthafa alMaraghi, Tafsir al-Maraghi, Juz ke11 ; h. 15)
Dalam hal ini berlaku qaidah "al'Ibrah bi 'Umum al-Lafzi, La bi Khushush al-Sabab”.

Kesimpulan ini diperkuat dengan tindakan Khalifah Abu Bakar yang memungut zakat dan memerangi orang yang tidak mau menyerahkan zakat kepadanya., sehingga Abu Bakar pernah berkata : Demi Allah kalau ada yang menahan atau mencegah untuk memberikan kepadaku zakat (Tafsir al-maraghi; h. 16) yang telah mereka serahkan kepada Rasulullah sungguh aku akan memeranginya (Kebijakan ini disepakti oleh para sahabat lainnya dan diikuti oleh khalifah-khalifah sesudahnya.

Di samping itu dalam banyak hadis juga diterangkan, bahwa di saat Rasulullah menugaskan sahabat untuk menjadi gubernur di sebuah daerah, beliau selalu memberikan tugas kepada mereka yang di antaranya adalah perintah untuk memungut zakat dari orang-orang kaya dan membagikannya kepada orang-orang miskin. Seperti pada saat Rasulullah mengutus Mu'az ibn Jabal menjadi gubernur di Yaman.

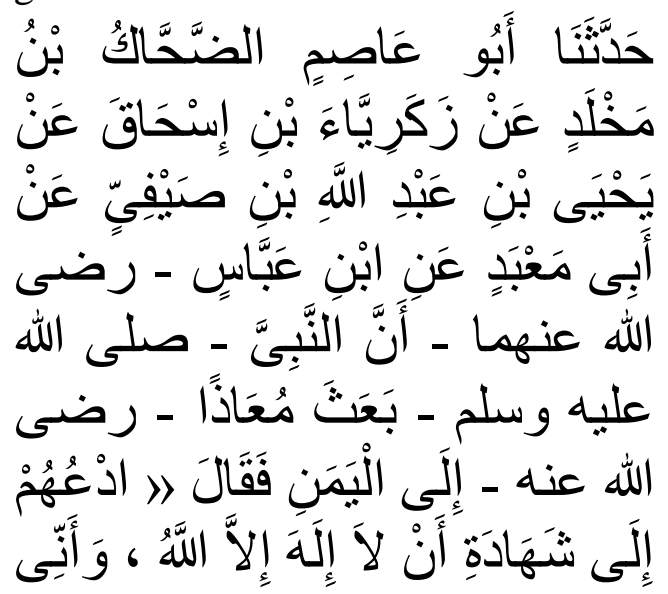




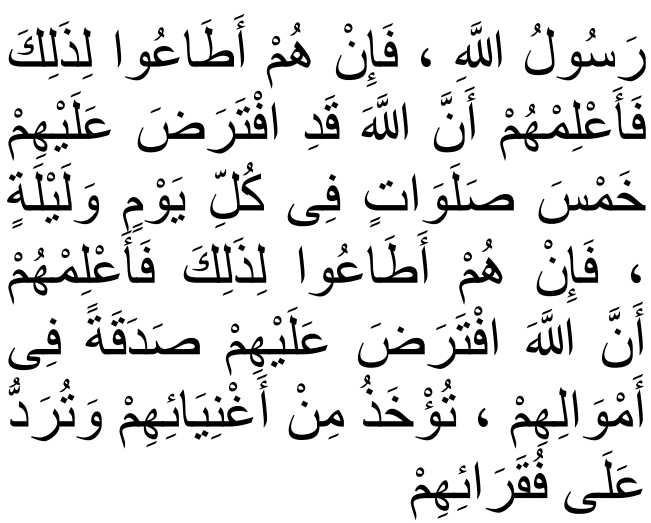

Bahwa Rasulullah Saw mengutus Muaz ke yaman, kemudian Rasulullah berkata, :"serulah mereka untuk bersaksi Tiada Tuhan Kecuali Allah dan bahwa saya adalah utusan Allah, maka apabila mereka telah mematuhi hal itu, maka beritahukan kepada mereka bahwa Allah mewajibakan mereka shalat lima kali sehari semalam, dan apabila mereka telah memathuinya, maka beritahukan kepada mereka bahwa mewajibklan zakat dari harta mereka, yang diambil dari orang kaya mereka dan bagikan kepada orang miskin di atanara merak. (HR Bukhari)

Adapun makna perintah pada ayat ini, menurut mayoritas Ulama, di antara Imam al-Razi dalam tafsirnya Mafatih al-Ghaib mengatakan kalimat amar “خُ (ambillah) disini adalah untuk wajib artinya wajib bagi yang diperintahkan untuk mengambil dari harta umat Islam, sesuai dengan qaidah ushul fiqh, bahwa hukum dasar dari amar itu adala wajib ("الأصل ("). Maka Rasulullah, para khulafaurrasyidin dan pemimpinpemimpin umat islam berikutnya memiliki kewajiban untuk menungut zakat dari orang-orang yang wajib zakat dan untuk kemudian membagikan kepada yang berhak menerimanya (Fakhruddin al-Raziy, Mafatih al-Ghaib, h. 203)

Di saat pemimpin memiliki kewajiban untuk memungut zakat, lalu apakah umat Islam memiliki kewajiban untuk menyerahkan zakat melalui pemimpinnya atau mereka masih memiliki kebebasan dalam membagikan zakatnya sendiri, tentang hal ini penulis akan paparkan beberapa pendapat para ulama fiqh yang mungkin dapat dijadikan sebagai dasar dalam menformulasikan pendapat yang lebih kuat dalam lebih relevan untuk konteks saat ini :

Menurut Imam Malik, apabila ada seorang Imam yang adil memungut zakat, maka tidak ada peluang bagi seorang muzakki untuk membagikan zakatnya sendiri baik dalam bentuk uang maupun yang lainnya, tetapi ia harus menyerahkannya kepada Imam (pemimpin) tersebut ${ }^{1}$.

Imam Syafi'I dalam qaul jadid-nya mengatakan bahwa menyerahkan zakat kepad Imam hukumnya tidak wajib, dan pemilik harta boleh saja membagikannya sendiri. Adapun jika imamnya jair, maka tidak boleh menyerahkan zakat kepadanya, tetapi apabila imamnya adil maka pemilik harta boleh

${ }^{1}$ Malik ibn Anas Ibn Malik al- Ashbihi, alMudawwanah, Juz 1, teks aslinyaadalah وقال مالك : إذا كان الإمام يعدل لم يسع الرجل أن يفرق زكاة ماله الناض و الا غير ذلك ولكن يدفع زكاة الناض لاض لإن إلى الإمام 
memilih apakah dia akan menyerahkanya sendiri atau menyerahkanya melalui imam. Lebih lanjut beliau juga menjelaskan bahwa jika harta itu bersifat zhahir maka lebih afdhal diserahkan kepada pemimpin, sedangkan jika zakat harta yang bathin maka lebih baik dia menyerahkannya sendiri. ${ }^{2}$

Menurut Ibnu Abu Musa dan Abu al-Khatthab, menyerahkan zakat kepada imam yang adil hukumnya afdhal. Menurut al-Sya'biy, Muhammad ibn Aliy, Abu Razin, Imam al-Auza'i menyerahkan zakat kepada imam afdhal, karena dia lebih mengetahui objeknya, dan menyerahkan kepada imam atau pemimpin sudah membebaskan muzakki baik secara zahir maupun batin

Imam Malik, Abu Hanifah, Abu 'Ubaid dan Qaul Qadim Imam syafi'I, membagi antara zakat harta yang zhahir seperti tanaman, pertambangan dan sebagianya, dan

${ }^{2}$ Al-Mawardi, Kitab al-Hawiy al-Kabir, Teka asli :

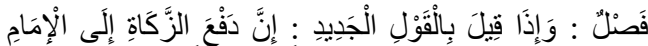

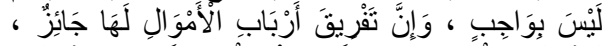

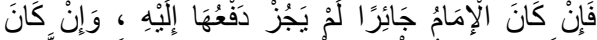

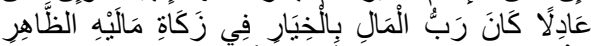

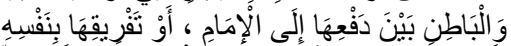

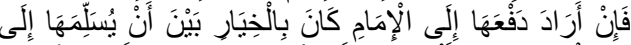

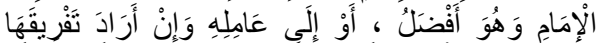

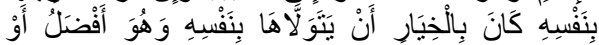
بوَ بَكِيلهِ .

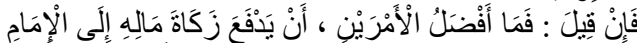

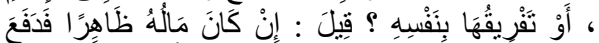

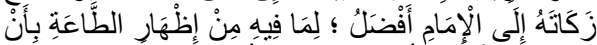

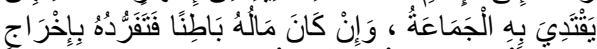

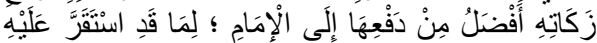

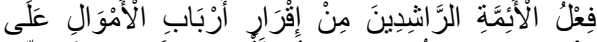

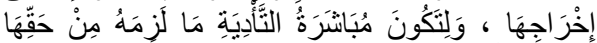

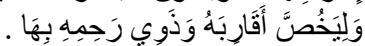

harta batin seperti emas, perak dan perdagangan. Maka zakat harta zhahir wajib menyerahkannya kepada imam (pemerintah) karena Abu Bakar memungutnya dan memerangi orang yang tidak mau menyerahkannya, dan hal itu juga disetujui atau disepakati oleh para sahabat. Oleh sebab itu tidak ada hak muzakki untuk menyerahkan atau membayarakannya sendiri, bahkan pengikut syafi'iah menegaskan kalau seandainya muzakki menyerahkannya sendiri maka itu tidak lah memadai (sah). ${ }^{3}$

Adapun zakat harta yang batin, maka kalangan hanafiyah berpendapat bahwa, Imam atau pemerintah memiliki kewajiban untuk memintanya. Hak memungut zakat tetap ada pada imam pada setiap harta yang wajib dizakatkan, berdasarkan ayat (al-Taubah 103). Adapun khalifah Ustman menyerahkan atau memberikan kebesan kepada pemilik untuk mneyerahkan langsung zakat harta batin karena mereka adalah pengantinya (wakilnya) dan ini pada dasarnya tidak menggugurkan kewajiban imam, oleh sebab itu kalau dia mengetahui suatu penduduk

\footnotetext{
${ }^{3}$ Kementrian Wakaf dan Urusan Islam Kuawait, Mausu'ah al-Fiqhiyyah teks aslinya adalah : فذهب ماللك وأبو حنيفة وأبو عبيدٍ ، وهو القديم من قولي

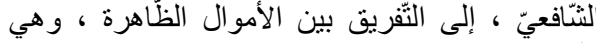

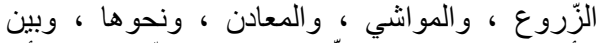

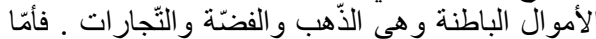

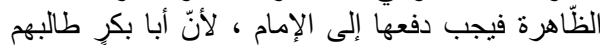

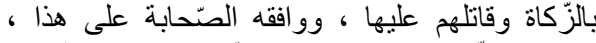

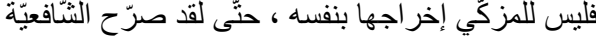

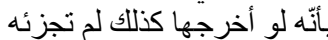


negeri tidak membayarkan zakat mereka, maka imam atau pemimpin wajib memungutnya, adapaun apabila imam tidak memungutnya maka tidak wajib menyerahkan kepadanya. ${ }^{4}$

Menurut Malikiyyah dan syafi'iyyah, zakat harta bathin diserahkan kepada pemiliknya, maka muzakki boleh menyerahkan kepada fakir miskin atau mustahiq lainnya. Pengikut Imam Hanbali berpendapat bahwa menyerahkan zakat kepada Imam tidak wajib baik untuk zakat harta zahir dan harta bathin, maka boleh bagi muzakki menyerahkan hartanya secara langsung, berdasarkan qias harta zhahir kepada harta bathin, kemudiuan pengikut syafi'yyah dalam pendapatnya yang lebih populer bahwa menyerahkan kepada Imam lebih baik dari pada membagikannya sendiri, karena imam lebih tahu dengan para mustahiq dan lebih mampu untuk membagikan diantara mereka. ${ }^{5}$

${ }^{4}$ Mausu'ah Fiqhiyyah, tekls aslinya adalah :

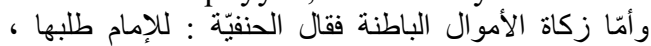

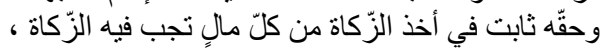

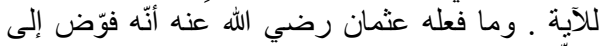

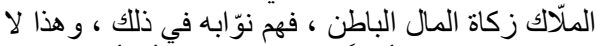

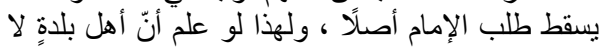

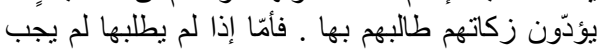

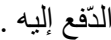

\footnotetext{
${ }^{5}$ Mausu'ah, teks asli :

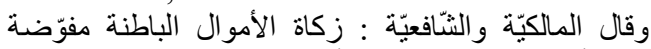

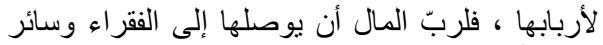

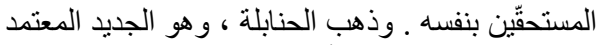

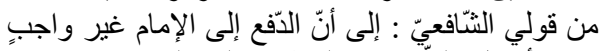

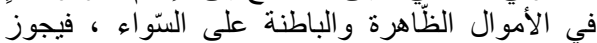

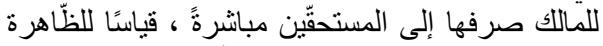

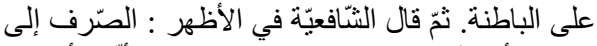

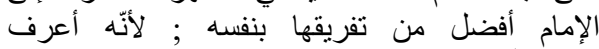

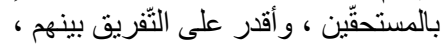

Adapun kalau imam yang adil memungut zakat maka ulama sepakat wajib menyerahkan kepadanya, baik zakat harta zhahir maupun zakat harta bathin. Dan Perbedaan tentang haknya dalam mengumpulkan zakat harta bathin tidak bisa dijadikan alasan pembolehan untuk berbuat makshiat kepadanya jika dia memintanya, karena objek pembahasan ini adalah objek ijtihad. Dan keputusan atau perintah Imam menghilangkan khilaf, seperti halnya hukum (keputusan) qadh. Bahkan pengikut Imam Malik juga menegaskan kalau seandainya imam yang adil meminta zakat, kemudian pemilik harta mengatakan bahwa dia sudah membayarkannya, maka pengakunnya tidak dapat diterima. ${ }^{6}$

\section{Pembentukan Amil Zakat}

Di dalam al-Quran, Allah swt telah menyebutkannya secara ekplisit adanya amil zakat sebagai orang atau lembaga yang ditugaskan untuk mengumpulkan zakat, yakni pada surat al-taubah ayat 60 :

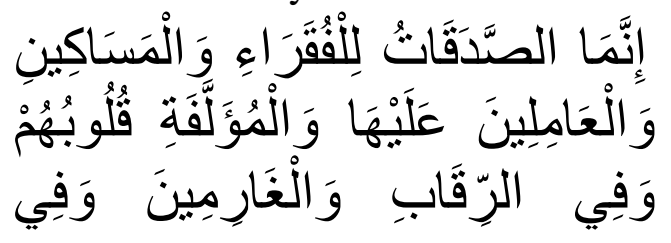

\footnotetext{
6 Mausu'ah Fiqhiyyah, teks asli :

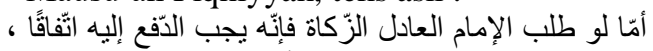

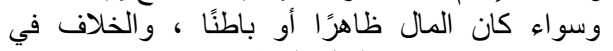

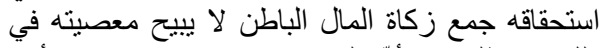

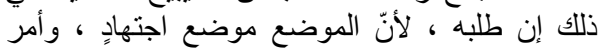

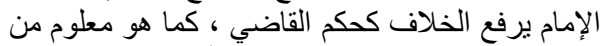

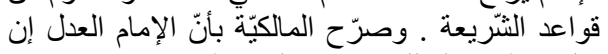

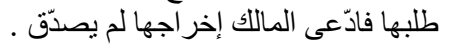




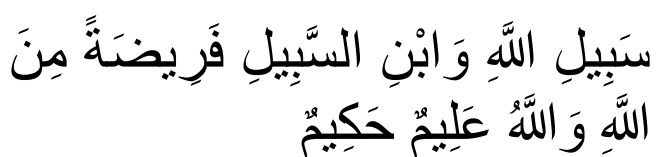

Artinya : Sesungguhnya zakat-zakat itu, hanyalah untuk orang-orang fakir, orang-orang miskin, penguruspengurus zakat, Para mu'allaf yang dibujuk hatinya, untuk (memerdekakan) budak, orang-orang yang berhutang, untuk jalan Allah dan untuk mereka yuang sedang dalam perjalanan, sebagai suatu ketetapan yang diwajibkan Allah, dan Allah Maha mengetahui lagi Maha Bijaksana.

Meskipun manthuq ayat ini berbicara tentang golongan yang berhak menerima zakat, yang di antaranya adalah amil zakat (orangorang yang mengelola zakat), tetapi mafhum dari ayat tersebut adalah bahwa kalau dari segi hak memperoleh zakat ada kelompok yang bernama Amil zakat, maka tentu ini merupakan isyarat dari Allah swt tentang adanya amil zakat, apakah itu dalam bentuk perorangan, lembaga atau badan yang dibentuk oleh pemerintah. Sehingga apabila dia sudah melaksanakan kewajibannya untuk melakukan penglolaan zakat baru ia sempurna menjadi orang atau kelompok yang menerima zakat.

Pada zaman Rasulullah Saw, peranan amil zakat ini pegang oleh baitul mal. Sehingga dalam kajian fiqh diketahui minimal ada empat jenis harta umat Islam yang masuk dan dikelola oleh Baitul Mal, yaitu zakat, pajak, harta rampasan, dan harta warisan yang tidak mempunyai ahli waris.

Di samping itu banyak hadis rasulullah yang menunjukkan bahwa pembayaran zakat harus melalui amil, dan bahkan jika sudah dibayarkan kepada amil maka lepaslah tanggung jawab muzakki, sebagaiman yang dijelaskan pada hadis-hadis yang dikutip dari kitab Mushannaf Ibnu Abi Syaibah:

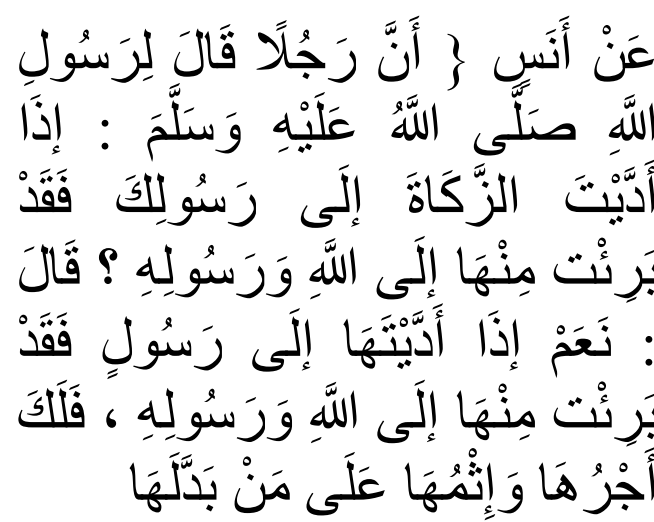

Artinya : dari Anas, "Seseorang bertany kepada Rasulullah SAW, : apabila aku serahkan zakat kepada untusanmua, apakah sudah lepas kewajibanku kepada allah dan Rasul ?, Rasulullah menjawab, apabila kamu sudah menyerahkan kepada utusan, maka kewajibanmu sudah lepas kepada Allah dan rasul-Nya, maka untuk-mu pahalamu dan dan dosa bagi orang yang menyelewengkannya.

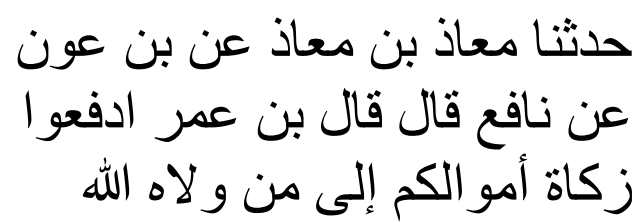




\section{أمركم فمن بر فلنفسه ومن أثم \\ فعليها}

Artinya : memberitkan kepada kami Mu'az ibn Mu'az, dari Ibnu 'Aun, dari Nafi', berkata, 'Ibnu Umar berkata, "Serahkanlah zakat hartamu kepada orang yang telah ditunjuk oleh Allah untuk mengurus urusanmu (pemimpin), siapa berbuat baik maka untuk dirinya, dan siapa yang berbuat dosa maka juga untuk dirinya.

حدثنا عبدة عن حارثة بن أبي

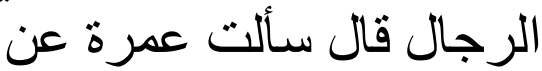
الزكاة فقالت قالت عائثة ادفعو ها

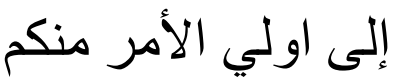

Artinya : memberitakan kepada kami 'Abdah dar haritsah ibn Abu Rijal, berkata, ditanya 'Imrah tentang zakat, kemudian dia berkata, "Aisyah r.a berkata, "serahkanlah kepada ulim amri di antara kamu".

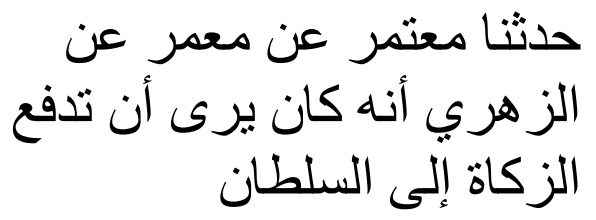

Artinya : Memberitakan kepada kami Mu'tami dari Ma'mar dari Imam alZuhri bahwa sesunbgguhnya dia berpendapat bahwa zakat diserahkan kepada pemimpin.

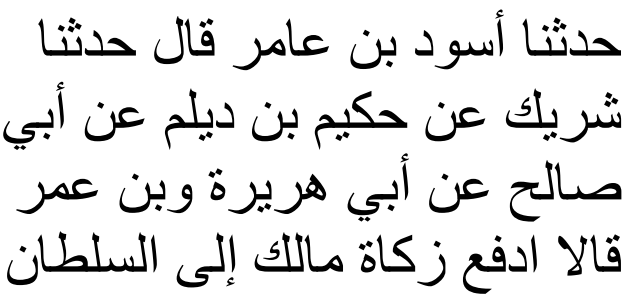

Artinya : memberitakan kepada kami Aswab Ibn Amir, memberitakan kepada kami Syariik dari Hakim ibn Dailam dari Abu Shalih dari Abu Hurairah dan Ibnu Umar, keduanya berkata : Serahkanlah zakatmu kepada sulthan (pemimpin)

Dari kajian di atas, dapat difahami bahwa ada beberapa aturan tentang pengelolaan zakat, pertama, pemerintah memiliki kewajiban untuk memungut zakat dari para muzakki, dan menyerahkannya kepada mustahiq sesuai dengan ketentuan agama. Kedua, untuk melaksanakan tugas pemerintah tersebut, Allah SWt mensyari'atkan adanya amil atau pengelola zakat. Dalam rangka mengimplementasikan konsep tersebut, pemerintah Republik Indoensia telah melahirkan Undangundang Nomor 23 tahun 2011, Peraturan Pemerintah Nomor 14 Tahun 2014, dan instruksi Presiden Nomor 03 Tahun 2014.

Dalam Pasal 5 UU nomor 23 tahun 2011, dijelaskan bahwa untuk melakukan pengelolaan zakat di Indonesia Pemerintah membentuk BAZNAS. Pada ayat 3 pasal 5 juga ditegaskan bahwa BAZNAS merupakan Lembaga Pemerintah Nonstruktural yang bersifat mandiri dan bertangungjawab kepada Presiden melelui Menteri. Dalam rangka menegaskan pengelolaan zakat melalui badan/lembaga yang ditunjuk Negara, maka pemerintah juga 
mengatur bahwa tidak ada lembaga yang boleh mengelola zakat kecuali yang sudah mendapatkan legitimasi dari pemerintah. Pada pasal 38 ditegaskan, "Setiap orang dilarang dengan sengaja bertindak selaku amil zakat melakukan pengumpulan, pendistribusian,atau pendayagunaan zakat tanpa izin pejabat yang berwenang".

Bahkan bagi yang melakukan pelanggaran terhadap pasal 38 tersebut, maka akan dipidana, seperti dijelaskan pada pasal 41, "Setiap orang yang dengan sengaja dan melawan hukum melanggar ketentuan sebagaimana dimaksud Pasal 38 dipidana dengan pidana kurungan paling lama 1 (satu) tahun dan/atau pidana denda paling banyak Rp50.000.000,00 (lima puluh juta rupiah)".

Untuk mengoptimlakan pengelolaan zakat di Indonesia, maka Presiden Republik Indonesia juga telah mengeluarkan Instruksi Presiden Nomor 03 Tahun 2014, yang menegaskan kepada seluruh kementerian dan Kepala Daerah untuk mengoptimalkan penyaluran zakat melalui BAZNAS.

\section{URGENSI}

\section{MELALUI AMIL}

Secara syar' $i$ telah dijelaskan bahwa Allah Swt menuntut umat Islam untuk membayarkan zakat melalui Amil dan tidak membayarkannya secara individual oleh muzakki. Pembayaran dan pengelolaan zakat melalui amil sangat relevan dan sesuai dengan prinsipprinsip dasar zakat itu sendiri, seperti:

\section{Zakat dapat menumbuhkan kehidupan orang miskin menjadi lebih baik}

Realitas selama ini menunjukkan bahwa banyaknya zakat yang dibayarkan oleh umat Islam tidak mampu mengurangi tingkat kemiskinan yang ada ditengah umat Islam itu sendiri, atau pendistribusian zakat yang dilakukan selama ini oleh banyak muzakki justru malah menambah tingkat kemiskinan dan bahkan menimbulkan dampak negatif yang sangat buruk, seperti kasus yang terjadi di pula Jawa yang hanya karena menunggu pembagian zakat dengan nominal Rp 30.000,meninggal sebanyak 21 orang. Hal Ini tidak sesuai dengan makna dan tujuan zakat al-numuw (tumbuh dan berkembang)

Dengan berzakat melalui amil, dana zakat yang selama ini terpisahpisah dan didistribusikan dengan nominal yang sangat kecil dapat dihimpun sehingga menjadi kekuatan dana yang cukup besar. Menurut Ketua Umum Badan Amil Zakat Nasional (Baznas), KH Didin Hafidhuddin Potensi zakat di Indonesia mencapai Rp 19,3 triliun setiap tahunnya ${ }^{7}$. Jika potensi dana

7 Ceramah KH Didin Hafidhuddin pada peluncuran Unit Pelayanan Zakat (UPZ) Bait Al-Kamil di Jakarta, Rabu (19/8). 
yang besar ini terkumpul dan terkelola secara professional maka tentu akan mampu mengurangi tingkat kemiskinan.

\section{Menghindarkan muzakki dari ria dan merasa berjasa}

Pendistribusian zakat secara langsung oleh muzakki kepada mustahiq terkadang menimbulkan perasaan ria, merasa berjasa atau dermawan. Pada hal ketika dilihat dari subtansi zakat seorang muzakki tidak boleh merasa berjasa apalagi ria dengan barzakat karena pada hakikatnya yang mereka bayarkan atau serahkan bukanlah harta mereka tetapi memang hak fakir miskin yang dititipkan oleh Allah pada rizki mereka. Sebagaimana firman Allah swt pada surat al-Ma'arij : 25 :

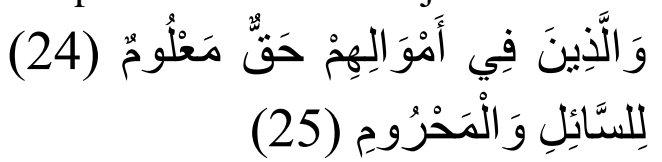

Artinya : (24) dan orang-orang yang dalam hartanya tersedia bagian tertentu, (25). bagi orang (miskin) yang meminta dan orang yang tidak mempunyai apa-apa (yang tidak mau meminta), (QS al-Ma'arij : 24-25)

\section{Menghindarkan fakir miskin dari tekanan dan kehinaan}

Karena orang kaya tidak boleh ria dan merasa berjasa dengan berzakat, maka sebaliknya para fakir miskin tidak boleh terhina atau

http://infokito.wordpress.com/2009/08/21/ potensi-zakat-indonesia direndahkan dengan menerima zakat karena yang mereka terima adalah haknya. Para fakir miskin menerima zakat semestinya dengan "kepala tegak" layaknya seorang pegawai yang mendapatkan gaji setiap bulan dari Negara. Hal ini juga sudah diisyaratkan Rasulullah SAW melalui hadis-hadisnya ketika bicara pendistribusian zakat rata-rata ترد Rasulullah Saw menggunakan kata yang dalam bahasa Indonesia berarti "kembalikan" bukan serahkan.

Realiatas pendistribusian zakat secara langsung oleh muzakki sering menempatkan fakir miskin pada posisi di bawah dan muzakki pada posisi di atas, pada hal secara syar'I itu tidak boleh terjadi. Maka untuk mengantisipasi hal tersebut agama telah membatasi antara muzaki dengan mustahiq dan pembatas itu adalah amil zakat, sehingga idealnya amil yang mengambil dari muzakki dan amil yang mengembalikan kepada mustahiq.

\section{Zakat terdistribusi secara adil dan merata}

Zakat sebagai salah satu pilar kekuatan ekonomi Islam tentu harus dapat terdistribusi secara merata dan adil tanpa harus melihat hubungan kekerabatan. Jika zakat dibagikan langsung oleh muzakki maka kecenderungannya adalah membagikan kepada karib kerabatnya sendirisendiri dan ini tidaklah adil bagi fakir miskin yang tidak memiliki kerabat yang kaya. Tetapi jika zakat sudah 
dihimpun oleh amil maka amil wajib membagikannya secara adil dan proporsional tanpa harus memperhitungkan nilai-nilai kekerabatan.

\section{Memenuhi prinsip syariat}

Realitas pendistribusian zakat secara langsung selama ini menunjukkan bahwa sering pendistribusian zakat itu tidak sesuai dengan prinsip dan ketentuan agama, seperti kebanyakan zakat bangsa Indonesia sudah menjelma menjadi masjid-masjid yang megah yang dikelilingi oleh fakir miskin yang kekurangan makan. Pada hal banyak ulama yang berpendapat bahwa zakat itu untuk orang bukan untuk barang atau benda. Demikian juga banyak para pengusaha yang membagikan zakatnya di kampung halamannya, pada hal di antara prinsip zakat itu adalah bahwa zakat harus dibagi dimana harta itu dihasilkan

Dengan menyalurkan zakat melalui amil maka berbagai kesalahan dan ketimpangan dalam penditribusian zakat tersebut tentu dapat diatasi, sehingga zakat terkumpul, terkelola dan terbagi sesuai dengan prinsip dan ketentuan syar'i.

\section{KESIMPULAN}

Allah Swt telah memerintahkan kepada setiap pemimpin umat Islam agar memungut zakat dari para muzakki (aghniya) dan menyalurkannya pada mustahiq (faqir miskin). Untuk merealisasikan perintah tersebut, pemimpin dapat membentuk amil zakat, sebagaimana yang juga sudah dicontohkan oleh Rasulullah SAW dan Khulafaurrasyidin.

Dalam konsep ketaatan terhadap pemimpin, ulama sepakat bahwa rakyat wajib patuh kepada pemimpin selama pemimpin itu memerintahkan melaksanakan kebenaran apalagi perintah dalam rangka menjalankan perintah Allah SWT. Apabila pemimpin sudah menunjuk amil zakat dan memerintahkan untuk memungut zakat dari para muzakki maka wajib bagi muzakki untuk membayarkan zakatnya melalui amil zakat.

Dengan menyalurkan zakat melalui amil yang dibentuk oleh pemerintah maka zakat yang dibarkan diharapkan dapat menumbuhkan kehidupan orang miskin menjadi lebih baik melalui program pemberdayaan, muzakki dapat terhindar dari sikap ria dan merasa berjasa, disamping fakir miskin terhindar dari merasa hina. Pembayaran zakat melalui amil juga akan mampu menjamin terdistribusinya zakat secara merata dan sesuai dengan prinsip syariah.

\section{DAFTAR PUSTAKA}

Abu Ja'far Muhammad ibn Jarir alThabari, Tafsir Jami' al-Bayan fi Ta'wil Ayi al-Quran. Beirut: Dar al-Nasyr, t.th

Ahmad Musthafa al-Maraghi, Tafsir al-Maragi, Kairo Musthofa alBabi al-Halabiy, t.th 
Fakhruddin al-Raziy, Tafsir Mafatih al-Ghaib, Beirut : Dar Ihya' al_Turats Islamiy, 1995

Imad al-Din Abu al-Fidak Isma'l ibn Umar Ibn Katsir, Tafsir alQur'an al-'Azhim, Beirut : Dar al-Kutub al-'Ilmiyyah, t.th

Kementerian Waqaf dan Urusan Islam Kuwait. Mausu'ah alFiqhiyyah, Kuwait ; Kementerian Waqaf dan Urusan Islam Kuwait, 1983
Muhammad Isma'il al-Bukhari, Shahih Bukhari, Beirut : Dar alKutub al-'Ilmiyah, 1992

Wahbah al-Zuhailiy, Al-Fiqh al-Islam wa Adillatuhu, Damsyiq : Dar al-Fikr, 2006

Yusuf Qardawiy, Fiqh Zakat Mausu'ah al-Fiqhiyyah, Beirut: Mu'assisah al-Risalah, t.th 